\title{
An Examination of Kindergarten Core-Reading Instruction in the United States
}

\author{
Mary Beth Marr \\ Behavior and Reading Improvement Center, UNC Charlotte \\ Cary, NC 27519, USA
}

Tell: 1-704-526-7970Ｅ-mail: mbmarr@mindspring.com

Bob Algozzine (Corresponding author)

EDLD/COED, University of North Carolina at Charlotte

Charlotte, NC 28223, USA

Tel: 1-704-687-8859Ｅ-mail: rfalgozz@uncc.edu

\author{
Kate Algozzine
}

Department of Educational Leadership/UNC Charlotte

Charlotte, NC 28223, USA

Tel: 1-704-687-8859_E-mail:kmalgozz@uncc.edu

\author{
Shawnna Helf
}

Winthrop University, Rock Hill, SC, USA

Tel: 1-803-323-2578 E-mail: helfs@winthrop.edu

Received: February 9, $2012 \quad$ Accepted: February 25, $2012 \quad$ Published: May 1, 2012

doi:10.5539/jedp.v2n1p80 URL: http://dx.doi.org/10.5539/jedp.v2n1p80

Support for this research was provided in part by Grant No. H238X00001 from the U.S. Department of Education, Office of Special Education Programs, awarded to the University of North Carolina at Charlotte. The opinions expressed are those of the authors and do not reflect a position, policy, or endorsement from the Department of Education.

\begin{abstract}
Prevention, intervention, and research efforts are grounded in a belief that teachers should only use alternative educational practices after reasonable evidence has indicated that general education practices implemented with a high degree of integrity have been unsuccessful. To investigate levels of implementation of an evidence-based primary reading program, we observed teachers' use of Open Court, a commercially-available core reading program, during the district-mandated two-hour literacy block. We found that the amount and type of literacy and language arts instruction children received varied across classrooms. We discuss the implications of our work for future research and the improvement of childhood education practices.
\end{abstract}

Keywords: Core-reading instruction, Kindergarten students, Evaluation

\section{Introduction}

The problem of significant reading failure in America has been the target of large-scale federal initiatives where many children with significant discrepancies between their expected and actual performance in reading receive remedial instruction. Beginning in the late 1960s, the field of learning disabilities emerged in response to large 
numbers of children failing to profit in general education (Ysseldyke \& Algozzine, 1982; 1984; Fuchs \& Deshler, 2007; Fuchs \& Fuchs, 2006; Fuchs, Mock, Morgan, \& Young, 2003). Despite considerable discontent, disagreement, and dissatisfaction related to critical underlying assumptions and constructs (i.e., identification, assessment, and intervention), the field grew dramatically throughout the 1980s and 1990s to a point where more than half of the more than 6 million children receiving special education services were classified with learning disabilities (Ysseldyke, Algozzine, \& Thurlow, 2000). Recently, the concerns reached a critical state largely because the growing numbers of students with the learning disabilities label made it increasingly difficult for local, state, and federal education agencies to fund the costs of "individualized" educational programs and the search for alternative identification practices became the driving force of innovation and reform in a field and category in serious need of "reconsideration" (Vaughn \& Fuchs, 2003, p. 138).

Response-to-Intervention (RTI) has emerged as the latest policy and programmatic practice promising to reduce the number of children referred to learning disabilities or special education programs by providing intensive and effective instruction before they begin to fail (Al Otaiba et al., 2011; Al Otaiba, Hosp, Smartt, \& Dole, 2008; Al Otaiba, Lake, Greulich, Folsom, \& Guidry, 2012; Al Otaiba, Kosanovich-Grek, Torgesen, Hassler, \& Wahl, 2005; Al Otaiba \& Fuchs, 2002; Baker, Fien, \& Baker, 2010: Farstrup, 2007; Fuchs, Fuchs, \& Compton, 2004; Fuchs, D., \& Fuchs, 2006; Fuchs, L. S. \& Fuchs, 1998; Fuchs, Fuchs, \& Speece, 2002; Gersten et al., 2008; Gersten \& Dimino, 2006; Vaughn \& Fuchs, 2003; Vaughn, Linan-Thompson, \& Hickman, 2003). RTI's prominence was promoted with its inclusion as part of federal legislation supporting educational support for individuals with disabilities and its potential as a critical feature of continuing educational reforms spurred by No Child Left Behind (NCLB). RTI "was 'very hot' in 2008, and some, including professionals in the International Reading Association, believed that if the heat kept building, [it] might boil into the 'hottest' of the hot range in 2009 in the 'What's hot, what's not' annual survey of literacy topics (What's hot focus topics, 2007, p. 12). Interestingly, proponents of RTI have accepted the accolade of high science (i.e., evidence-based practice) in the absence of data demonstrating effectiveness:

"...there is insufficient evidence of the effectiveness of RTI approaches...[f]ew published or unpublished studies are available" and those that are "...have typically involved small (or undefined) samples of schools, teachers, and students, and offer little information about what interventions are implemented, with what degree of accuracy of effectiveness...The absence of such evidence weakens an important assumption among RTI advocates, namely that RTI provides feasible, timely, and effective interventions. Only feasible, timely, and effective interventions permit one to claim that RTI is preventive for many, and that it distinguishes struggling students with disabilities from others struggling because of inadequate prior instruction." (Fuchs, Mock, Morgan, \& Young, 2003, p. 166)

Regardless of this shortcoming, education professionals promote RTI based on its hypothesized usefulness in identifying students with learning disabilities as well as its potential for preventing academic failure among all students (Cassidy \& Cassidy, 2008, 2009, 2010; Fuchs, Mock, Morgan, \& Young, 2003; Gersten \& Dimino, 2006; Gresham, 2002; Johnson, Mellard, Fuchs, \& McKnight, 2006; Learning Disabilities Roundtable, 2002, 2005; Mellard, 2004; National Research Council, 2002; President's Commission on Excellence in Special Education, 2002; Vaughn \& Fuchs, 2003).

In a recent report, the National Joint Committee on Learning Disabilities (NJCLD: 2005) noted that the "core concepts of an RTI approach are the systematic (1) application of scientific, research-based interventions in general education; (2) measurement of a student's response to these interventions; and (3) use of the RTI data to inform instruction" and that evidence of the following should be included in the process:

1) High quality, research-based instruction and behavioral supports in general education.

2) Scientific, research-based interventions focused specifically on individual student difficulties and delivered with appropriate intensity.

3) Use of a collaborative approach by school staff for development, implementation, and monitoring of the intervention process.

4) Data-based documentation reflecting continuous monitoring of student performance and progress during interventions.

5) Documentation of parent involvement throughout the process.

6) Documentation that the timelines described in the federal regulations $\S 300.532-300.533$ are adhered to unless extended by mutual written agreement of the child's parents and a team of qualified professionals as described in $\S 300.540$. 
7) Systematic assessment and documentation that the interventions used were implemented with fidelity. (p.3, emphasis added)

We were interested in the beginning and the end of the list of expectations guiding RTI: The extent to which high quality, research-based core-reading instruction was implemented with fidelity in kindergarten classrooms. We reasoned that consideration of treatment fidelity, or the extent to which an intervention was implemented as intended, was essential in efforts to evaluate the efficacy, effectiveness, and success of educational programs and practices for young children, especially those experiencing or likely to experience school failure (Bellg et al., 2004; Wallace, Blase, Fixsen, \& Naoom, 2008)

\subsection{Core-reading Research}

The guiding principles embodied in RTI are well-known in the effective and high-performing schools literature (cf. Baker, Fien, Baker, 2010; Blachman, Tangel, Ball, Black, \& McGraw, 1999; Bryk \& Schneider, 2002; Denton, Foorman, \& Mathes, 2003; Foorman, 2007; Foorman \& Torgesen, 2001; McCutchen, Harry, Cunningham, Cox, Sidman, \& Covill, 2002; Shannon \& Bylsma, 2007; Snow, Burns, \& Griffin, 1998; Taylor, Pearson, Clark, \& Walpole, 2000). A variety of studies have shown that these characteristics interact with factors at the school-, teacher-, and student-level (Connor, Jakobsons, Crowe, \& Meadows, 2009; Connor, Morrison, \& Katch, 2004; Connor, Morrison, \& Slominski, 2006; Connor, Morrison, \& Underwood, 2007; Connor, Son, Hindman, \& Morrison, 2005; Foorman, Francis, Davidson, Harm, \& Griffin, 2004; Foorman, Francis, Fletcher, Schatschneider, \& Mehta, 1998; Foorman \& Moats, 2004; Foorman, Schatschneider, Eakin, Fletcher, Moats, \& Francis, 2006; Foorman \& Torgesen, 2001; Simmons et al., 2007; Taylor et al., 2000). Less research has addressed how reading is being taught or the extent to which these or other features are implemented with fidelity in schools using high quality, research-based core-reading programs. To address this need, the International Reading Association (IRA) recently created the Status of Reading Instruction Institute (SRII) to provide accurate and detailed descriptions of reading instruction in public schools in the United States. A first step in ongoing research (http://www.reading.org/resources/issues/status.html) to improve reading instruction for this group is providing descriptions of how reading is being taught in the classroom (IRA, 2007). Toward that end, working with a team of researchers from the University of Michigan, SRII is sponsoring a study of reading instruction in a nationally representative sample of first and fourth grade classrooms in the United States. Data collection will take place in the 2009-10 school year and the outcomes of this important work are expected to be released at the IRA convention in 2011 (K. Douglas, email communication). The need for continued study of what constitutes effective reading instruction is long-standing and critical; in this regard, we were interested in how kindergarten teachers were teaching reading in our school district. Specifically, we were interested in answering two questions:

1) To what extent are key content areas addressed in core-reading program instruction in kindergarten?

a. How much time is spent on different areas of early literacy instruction during the district's mandated 120-minute literacy block relative to recommended core-reading program time allotments?

b. What is occurring during the time spent on different areas of early literacy instruction?

2) To what extent are key core-reading program elements evident in kindergarten classrooms?

a. What program elements are teachers using to support early literacy instruction?

b. What resources are teachers using to support early literacy instruction?

We reasoned that while many factors interact to produce successful (and unsuccessful) readers, collecting information about how teachers implement a core-reading program was essential to understanding and defining the base for all other efforts to address reading problems within the context of RTI and other "reform," "reconsideration," or "rethinking" activities.

\section{Method}

\subsection{Context, Setting, and Participants}

The Behavior and Reading Improvement Center (BRIC) was a federally-funded project designed to implement and evaluate school-based interventions for children in grades K-3 who were identified as having marked difficulty learning to read and/or who exhibited serious behavioral problems. Seven schools in an urban district in the southeast United States were selected based on a history of low performance and high risk factors (e.g., historically high poverty enrollments). BRIC project schools enrolled more children from ethnic minority backgrounds than other schools in the district, particularly African-American children. While representing a slight majority in the district (40\%), Caucasian children represented less than $15 \%$ of the students attending all 
but one BRIC school. Percentages of Hispanic children were above the school system average in four of the BRIC schools (Algozzine, et al., 2012). All teachers met state certification standards; each was licensed to teach in elementary school and held at least a bachelor's degree in education.

The participating school district had adopted the widely-used (cf. Education Market Research, 2002, 2005, 2007) Open Court Reading (C2000 (Bereiter et al., 2002; McGraw-Hill Education, no date; SRA/McGraw Hill, 2000) materials as its core reading program for all elementary schools. A random sample of approximately one-half of the kindergarten teachers in the BRIC project $(N=11)$ participated in this component of our research. All had received extensive professional development by local and national consultants as part of the district-wide adoption. Observations were conducted midway during their second year using the program.

\subsection{Materials}

Based on the Oregon Reading First Center's 2003 critical review of comprehensive curricula in beginning reading and other evidence, Open Court Reading has many characteristics of a strong program including systematic, explicit instruction in the big ideas of beginning reading (Al Otaiba et al., 2005; http://www.odc.state.or.us/cifs/grants/readingfirst). The program systematically and explicitly introduces children to letter shapes, sounds, and spellings with sufficient opportunities for students to practice and apply their developing phonics knowledge. Children received explicit blending instruction that gave them a strategy for accessing words they had not encountered while reading. They applied those skills to reading words fluently and effortlessly as well as building vocabulary so they could direct all of their cognitive energies to the true purpose of reading: making sense of text. Students consistently were exposed to text that allowed them to practice their developing knowledge of sound-symbol relationships. Typically, this meant reading stories that contained a high number of words that could be "sounded out" based on what teachers had already taught their students. Repeated practice reading words that used newly learned sounds and spellings helped students build fluency and vocabulary. Recognizing that accurate, rapid, expressive oral reading develops over time, Open Court Reading has a variety of decodable texts at multiple grade levels to allow many opportunities for practice and feedback.

\subsubsection{Instrumentation}

We used two observation forms developed in the participating school district to examine instruction and organization in classrooms implementing the Open Court Reading program. The Open Court Administrator's Guide (Roit, 2000) was used to create these documents. The Open Court Reading Instructional Checklist contained three parts. In Part I: Sounds and Letters, we recorded the time spent teaching sounds, letters, and language, phonemic awareness, and letter recognition. We also rated three qualitative aspects of sounds, letters, and language instruction (e.g., students' engagement, discussion of print concepts), five qualitative aspects of phonemic awareness instruction (e.g., activities focused on sounds not letters, students identifying sounds beginning, middle, and end of words), and three qualitative aspects of letter recognition instruction (e.g., activities focused on letter names and formation, workbook pages were guided and directed). In Part II, we recorded time spent and ten qualitative aspects of reading and responding (e.g., teacher read aloud from suggested book, teacher reviewed selection vocabulary prior to reading, teacher taught comprehension skills). In Part III: Integrating the Curriculum, we recorded time spent in independent work time and independent, collaborative, and whole group writing. We also rated eight qualitative aspects of independent work time (e.g., teacher introduced game, center, or activity prior to use by students, reading materials supporting unit theme were available for research and inquiry projects) and five qualitative aspects of independent, collaborative, and whole group writing (e.g., teacher provides direct instruction in writing, writing seminar is part of writing process).

We recorded the location and qualitative aspects of eleven key program elements (e.g., alphabet sound cards placed so all students could see them, writing area included a table with materials, journal, and folders) and four resources (e.g., Big Books, Decodables, Manipulative Kit) on the Classroom Organization for Open Court Checklist.

\subsubsection{Observers}

BRIC Center Support Coordinators (CSCs) were local school district employees assigned full-time to serve as lead teachers for the project. CSCs were knowledgeable about the reading interventions being implemented and provided ongoing support and specific feedback to participating staff on implementation issues. Prior to data collection, the first and third author met with four CSCs to practice using the forms. Teams of observers conducted independent, side-by-side practice observations, discussed their coding, and achieved consensus on areas of disagreement before using the two instruments in targeted classrooms. Inter-observer reliability (number of agreements / number of agreements + disagreements) across randomly selected practice observations was high 
(range $=.87-.93$ ) and considered acceptable for the purpose of our research.

\subsection{Procedure}

We completed "unannounced" observations of instruction during the last two weeks of January and the week of February. Two teachers each at the kindergarten level were randomly selected from six of the BRIC schools. In total 11 teachers were observed for a combined period of 23 hours of instruction. Each teacher was observed for roughly 2 hours each during the full district-mandated literacy block.

For the Open Court Reading Instructional Checklist, observers coded each area as follows: + equaled well done, check equaled satisfactory, NA equaled not applicable (or not observed). The second part of the observation was focused on classroom organization. In one column of the form, we looked at program elements like letter/sound cards or word walls and recorded the locations of these program elements, contents, etc. We coded these classroom elements as follows: a + equaled well done, check equaled satisfactory, and 0 equaled not available (not in the room). In the end, the "+" and "check" were equated to "yes" (or applicable or available or observed) as an indicator of the "quality" of the lesson based on expectations defined by the program developers.

We also looked at the amount of time spent on the various parts of the program. The teacher's manual recommends a time frame for each part of the lesson (e.g., letters and sounds, decodables, and so on) and we examined the extent to which teachers took more or less time on the lesson parts.

\subsection{Design and Data Analysis}

Our goal was to identify and document selected aspects of how teachers were implementing a core-reading program with kindergarten children in a sample of schools enrolling large numbers of at-risk students. We used direct assessment methods (Gresham, MacMillan, Beebe-Frankenberger, \& Bocian, 2000) by research team members focused on instructional components and classroom organization. We observed complete instructional sessions and documented the presence or absence of each targeted feature as well as time allocated to different instructional components recommended by the program developers through consultants and literacy facilitators supporting its implementation. For the instructional checklist, we coded each area as well done (2), satisfactory (1), or not applicable (0). For the classroom organization checklist, we looked at the location and use of key program elements like letter/sound cards or word walls and coded them as well done (2), satisfactory (1), or not available (0). Prior to conducting research observations, a team of former teachers/research assistants practiced using the observation instruments in two different classrooms to obtain inter-observer agreements of .85 or higher across pairs of observers.

\section{Results}

In general, our findings support the use of frequent monitoring and continuous support of primary reading instruction. For example, teachers using all phases of the Open Court program and the most commonly observed lesson parts included phonemic awareness, letter recognition, and independent work time, levels of implementation in Kindergarten classrooms were variable and opportunities for increased intensity were evident midway in the school year:

90\% taught Phonemic Awareness phase of the lessons,

$82 \%$ taught Letter Recognition phase of the lessons,

$73 \%$ taught the Reading and Respond phase of the lessons,

$63 \%$ taught Sounds, Letters, and Language phase of the lessons,

$82 \%$ included Independent Work Time during literacy block, and

$63 \%$ taught the Writing phase of the literacy lesson.

We also noted that on average, teaching time given to the following lesson parts was within the recommended ranges: Sounds, Letters and Language; Phonemic Awareness; and Read and Respond. The lesson phases of Letter Recognition, Independent Work Time, and Writing lasted slightly longer on average than the time recommended by the Open Court reading program. This "disconnect" between program recommendations for effective use of instructional time and actual teaching creates opportunities for less than optimal program effects, especially for some children (e.g., those requiring continuing high levels of implementation). Our observation of greater allocations to Independent Work Time is consistent with the finding of Connor, Morrison, and Katch (2004) who reported that "teachers in first grade "provided more TME [teacher-managed explicit] and CME [child-managed explicit] [instruction] at the beginning of the school year and significantly less as the year progressed" (p. 315). 
Additional outcomes illustrating what we observed during reading and literacy instruction and lessons in Kindergarten are in Table 1. We observed seven (64\%) teachers teaching the first phase of a scripted lesson (i.e., Sounds, Letters, and Language). All of the teachers we observed engaged children in the activity and most discussed print concepts as directed. Manipulation of words or pictures occurred half the time during this part of the lesson. We observed ten (91\%) teaching Phonemic Awareness and they all focused on sounds, not letters, engaged in word play, listened for sounds of words, and blended word parts. Nine (82\%) teachers were observed teaching Letter Recognition. All focused on letter names and formation. Five (45\%) teachers modeled how to form the letters for the students and five teachers guided the reading workbook pages completed by the students.

We observed eight (73\%) teachers during the Read and Respond part of literacy instruction. All of the teachers read aloud from the Big Books and reviewed selected vocabulary. At least half of these teachers encouraged students to make connections with the story, ask questions, and modeled comprehension strategies. Less frequently observed behaviors included browsing the big book before reading, making connections between the story and the unit themes, and explicitly teaching comprehension skills. More than half of these teachers used the Concept/Question Board and had their students working on unit projects.

We observed nine (82\%) teachers implementing Independent Work Time (IWT) during their literacy block. All of those observed had IWT on their class schedule. More than half of these teachers clearly labeled IWT areas in the classroom, posted IWT rules, had materials available for building fluency, and had an assistant available to provide support for instruction. Many times the teacher would introduce an to its use and provide direct instruction to students during this time. About one-fourth of these teachers provided reading materials that supported or integrated with the unit theme of study.

We observed seven teachers (64\%) engaging in independent, collaborative or whole group writing. Of these, more than half directly taught grammar skills, conferenced with students, or included other cross-curricular activities at this time activity prior. Fewer than half of the teachers provided direct instruction in using the writing process (prewrite, draft, revised, edit, publish).

Outcomes of observations related to key classroom organizational elements evident during core-reading instruction in Kindergarten are in Table 2. We observed all of the teachers use the alphabet sound cards and floor area consistent with the program recommendations. The majority of teachers implemented the word wall (approximately 91\%), reading area (approximately 73\%), writing area (approximately 64\%), concept/question board (approximately 91\%), pocket chart/cards (approximately 91\%), board area (approximately $73 \%$ ), and table area (approximately 73\%). Fewer teachers were observed using the listening area (approximately 54\%), and far less using the inquiry area (approximately 9\%). In terms of resources all teachers were observed using decodables and workbooks/reproducible and a majority used the big books (approximately 82\%) and manipulative kit (approximately 64\%).

\section{Discussion}

The search for the best approach for teaching children to read has fostered continued debate with the latest arguments spinning into calls for action touching all levels of interest in education (Al Otaiba, Kosanovich-Grek, Torgesen, Hassler, \& Wahl, 2005; Baker, Fien, Baker, 2010; Connor, Morrison, \& Katch, 2004; Dewitz, Leahy, Jones, \& Sullivan, 2010; Loveless, 2001; Martin, Martin, \& Carvalho, 2008; Ravitch, 2001). The continuing and profound levels of failure documented for many students and supported for some by special education has created renewed interest in prevention science and efforts to improve the academic and behavior instruction provided to all students (Algozzine, Daunic, \& Smith, 2010). All this effort misses a fundamental fact: The critical dimension in early reading instruction is the extent to which young children participate in evidence-based early literacy practices.

There is evidence that the amount and type of literacy and language arts instruction children receive varies across classrooms. For example, Wharton-McDonald, Pressley, and Hampston (1998) conducted observations and interviews to study nine $1^{\text {st }}$ grade teachers identified as effective literacy teachers. Based on student literacy achievement and engagement, three groups of teachers emerged as superior. These teachers integrated reading and writing activities, integrated multiple goals in a single lesson, and had an awareness of their practice and their underlying goals. Taylor et al. (2000) conducted a national study to determine the practices of effective teachers in schools serving high risk students. These results were compared with moderately effective and less effective schools. Findings suggest that effective classroom practices such as time spent in small reading groups and teacher directed activities in critical skills (e.g., phonics) contributed to success in the most effective schools.

Connor, Morrison, and Katch (2004) compared the amounts of "teacher-managed instruction" (i.e., direct teaching) and "child-managed instruction" (i.e., independent learning) in first grade classrooms and found that 
individualized instruction can lead to significant decoding skill growth. Students entering school with lower skills received more teacher directed responses, compared to students entering with higher skills who received more independent learning activities. Further, Connor, Jakobsons, Crowe, \& Meadows (2009) found different effects of instruction across grades and prior levels of student skills. They found that the amounts of explicit and implicit teaching and learning decreased while the amount of implicit learning increased over the course of a school year. They also found that the "effects of specific first-grade instructional practices on children's decoding skills depended in large part on children's entering vocabulary and decoding skills" or in a sense finding that the rich stay richer and the poor stay poorer despite decreasing levels of teacher-managed instruction over time (p. 327).

In our study, we found considerable variability in the extent to which teachers in Kindergarten classrooms implemented key instructional components (e.g., Sounds, Letters, and Language; Letter Recognition; Reading and Responding) of a scripted, evidence-based core reading program. We also documented variation in the extent to which critical program elements (e.g., reading area, listening area) and program resources (e.g., Big Books, Manipulative Kit) were integrated into the instruction in the same classrooms.

We did not expect that the conditions in the classrooms that we observed would be equal, but the inequities that we observed were unexpected. In Savage Inequalities, Kozol (1991) wrote eloquently of places where "very little [of the] education in the school would be considered academic in the suburbs" (p. 29). And, while it would be convenient to blame the "conditions" of the schools for the discrepancies we observed in our study, it would be inappropriate; in fact, there were similar resources and materials provided for every classroom in every school in the district. All teachers in every school received similar professional development and classroom-based support as part of the district-wide adoption of the core reading program that we observed. The schools in our research were randomly selected from a demographically similar pool and the students in the classrooms that we observed were more similar than different with regard to academic, behavioral, social, personal and family characteristics. In short, there were few, if any, obvious or outstanding community, school, or child inequalities to explain the variation that we observed. The implication of importance here is that monitoring the instruction children receive is as important as monitoring the outcomes children achieve from it. Put another way, simply directing that all children receive 120 minutes of core reading instruction a day is a potentially necessary, but probably insufficient approach to turning around the cycle of failure that is evident in many schools and that is the reason many children go to special education.

Response to intervention directs that "[b]efore data are gathered to determine if students are responsive to (or benefiting from) intervention, a subgroup of at-risk students is identified from which nonresponders are likely to emerge" and that this activity should occur in the first month of the school year (Fuchs \& Fuchs, 2007, p. 93). The logic here is that early identification of less than optimal performance pays dividends in efforts to improve learning for all students, especially those experiencing difficulties. The connections and implications for and from our research are direct: Administrators need to focus on the quality of instruction being provided in the classrooms of their schools with the same willfulness, intensity, and scrutiny that they direct their teachers to focus on the learning of their students. Simple tools and checklists are available or can be constructed to document the integrity of implementation of any intervention. Simple tools and checklists are available or can be constructed to document the extent to which key literacy skills (e.g., alphabet knowledge, phonological awareness, fluency, vocabulary, and comprehension) are being taught. In this context, effective practices prevent problems by ensuring that effective instruction is part of every child's educational program. As Algozzine, Putnam, and Horner (2010) point out, this means documenting that classroom-based interventions (e.g., district core reading program, school-wide discipline program) are implemented with fidelity before measuring outcomes and assigning worth to them or blaming children for not achieving them.

\subsection{Implications for Future Research and Improvement of Practice}

Using a rubric developed for their study, Al Otaiba et al. (2005) analyzed six core reading programs (including Open Court Reading) for evidence to support teachers in delivering high quality early literacy instruction. They found that the programs shared several features in addition to focus on components of scientifically based reading research (i.e., phonemic awareness, phonics, vocabulary, fluency, and comprehension), including “...explicit instructional strategies and consistent instructional routines and organization" (p. 377). While high quality curriculum materials are important influences on academic and behavior outcomes, most professionals agree that they are less important than the quality of the instruction that the students receive, especially in the early grades (Darling-Hammond, 1999; McCutchins et al., 2002; No Child Left Behind Act, 2002; Pressley et al., 2001; U. S. Department of Education, 2002). In this context, teaching and what teachers do is the foundation of the effective schools movement and all recent levels of school reform in the United States (Al Otaiba et al., 2012; 
Brown-Chidsey \& Steege, 2005; Darling-Hammond, 2000). For example, an educational "big idea" is that "[a]ll children deserve effective instruction that leads to achieving functional skills" and "high quality instruction" is a main component promised and essential for such practices as RTI (Brown-Chidsey \& Steege, 2005, p. 11). To our knowledge, this study is unique as a systematic analysis of key instructional behaviors of kindergarten teachers implementing a core reading program. We undertook the study in an effort to identify the extent to which critical features of the program were being implemented with fidelity. While our findings contribute to the important knowledge base, the need for future research, in which more direct observations are made across an entire school year will yield potentially richer data.

Similarly, there is a need for comparing levels of achievement for students in classrooms where core reading programs are taught with varied levels of fidelity. Such information would provide valuable formative guidance on which to build professional development opportunities that support effectiveness and positive changes in practice, both for beginning and experienced teachers as well as for professionals who coach and support them (Al Otaiba \& Fuchs, 2002; Al Otaiba et al., 2005, 2008, 2011, 2012; Mraz, Algozzine, \& Kissel, 2009; Mraz, Algozzine, \& Watson, 2008; Mraz, Kissel, Algozzine, Babb, \& Foxworth, 2011). Comparison data based on similarities and differences in implementation will also help to define minimum levels treatment fidelity needed to achieve successful outcomes and how much can teachers deviate from the program and still achieve positive outcomes with their core reading instruction.

\subsection{Limitations}

Our study was part of a larger effort designed to assess the effect of systematic and simultaneous implementation of a comprehensive reading model and schoolwide positive behavior support systems and practices (cf. Algozzine et al., 2012). As with all school-based research, our work had features that limit generalization and direct the need for continued study. Our design was primarily illustrative; that is, we were interested in describing an ongoing core reading program in the context of actual classroom practice. We did not document, assess, or predict relationships within or across the early literacy instruction that we observed. Our study was also limited to kindergarten instruction in a small number of schools. Participating teachers had been provided professional development by product provider consultants as part of the district-wide adoption. The settings in which we conducted the study were representative of schools enrolling large numbers of students at risk for learning and social behavior problems. For this study, we observed a relatively small number of teachers and observations were conducted over a short period of time. Further, we did not collect data on early literacy skills or reading achievement of students in each of these classrooms. While these features of our work limit generalization, we believe the restrictions they placed on our findings are reasonable in light of the preliminary nature of our study within the context of formal evaluation of core reading instruction implementation.

\section{References}

Al Otaiba, S., \& Fuchs, D. (2002). Characteristics of children who are unresponsive to early literacy intervention: A review of the literature. Remedial and Special Education, 23, 300-316. http://dx.doi.org/10.1177/07419325020230050501

Al Otaiba, S., Folsom, J. S., Schatschneider, C., Wanzek, J., Greulich, L., Meadows, J., \& Connor, C. M. (2011). Predicting first-grade reading performance from kindergarten response to tier 1 instruction. Exceptional Children, 77, 453-470.

Al Otaiba, S., Hosp, J. L., Smartt, S., \& Dole, J. A. (2008). The challenging role of a reading coach, a cautionary tale. Journal of Educational \& Psychological Consultation, 18, 124-155. http://dx.doi.org/10.1080/10474410802022423

Al Otaiba, S., Lake, V. E., Greulich, L., Folsom, J. S., \& Guidry, L. (2012). Preparing beginning reading teachers: An experimental comparison of initial early literacy field experiences. Reading and Writing: An Interdisciplinary Journal, 25, 109-129. http://dx.doi.org/10.1007/s11145-010-9250-2

Al Otaiba, S., Kosanovich-Grek, M. L., Torgesen, J. K., Hassler, L., \& Wahl, M. (2005). Reviewing core kindergarten and first-grade reading programs in light of No Child Left Behind: An exploratory study. Reading \& Writing Quarterly, 21, 377-400. http://dx.doi.org/10.1080/10573560591002286

Algozzine, B., Daunic, A. P., \& Smith, S. W. (2010). Preventing problem behaviors ( ${ }^{\text {nd }}$. ed.). Thousand Oaks, CA: Corwin.

Algozzine, B., Putnam, R., \& Horner, R. (2010). What we know about the relationship between achievement and behavior. In B. Algozzine, A. P. Daunic, \& S. W. Smith (Eds.), Preventing problem behaviors ( $2^{\text {nd }}$ ed.) (pp. 223-226). Thousand Oaks, CA: Corwin. 
Algozzine, B., Wang, C., White, R., Cooke, N., Marr, M. B., Algozzine, K., Helf, S. S., \& Duran, G. Z. (2012). Effects of multitier academic and behavior instruction on difficult-to-teach students. Exceptional Children.

Baker, S. K., Fien, H., \& Baker, D. L. (2010). Robust reading instruction in the early grades: Conceptual and practical issues in the integration and evaluation of tier 1 and tier 2 instructional supports. Focus on Exceptional Children, 42(9), 1-20.

Bellg, A. J., Resnick, B., Minicucci, D. S., Ogedegbe, G., Ernst, D., Borrelli, B., et al. (2004). Enhancing treatment fidelity in health behavior change studies: Best practices and recommendation from the NIH Behavior Change Symposium. Health Psychology, 23, 443-451. http://dx.doi.org/10.1037/0278-6133.23.5.443

Bereiter, C., Brown, A., Campione, J., Carruthers, I., Case, R., Hirshberg, J.,...Treadway,G.H. (2002). Open court reading. Columbus, $\mathrm{OH}$ : SRA McGraw-Hill.

Blachman, B. A., Tangel, D. M., Ball, E. W., Black, R., \& McGraw, C. K. (1999). Developing phonological awareness and word recognition skills: A two-year intervention with low-income, inner-city children. Reading and Writing: An Interdisciplinary Journal, 11, 239-273. http://dx.doi.org/10.1023/A:1008050403932

Brown-Chidsey, R., \& Steege, M. W. (2005). Response to intervention: Principles and strategies for effective practice. New York, NY: Guilford.

Bryk, A. S., \& Schneider, B. (2002). Trust in schools: A core resource for improvement. New York: Russell Sage.

Cassidy, J., \& Cassidy, D. (2008, Feb/March). What's hot for 2008? Reading Today, 25(4), 1, 10-11.

Cassidy, J., \& Cassidy, D. (2009, Feb/March). What's hot for 2009? Reading Today, 26(4), 1, 8-9.

Cassidy, J., \& Cassidy, D. (2010, Dec 2009/Jan 2010). What's hot for 2010? Reading Today, 27(3), 1, 8-9.

Connor, C. M., Jakobsons, L. J., Crowe, E. C., \& Meadows, J. G. (2009). Instruction, student engagement, and reading skill growth in Reading First classrooms. The Elementary School Journal, 109, 221-250. http://dx.doi.org/10.1086/592305

Connor, C. M., Morrison, F. J., \& Katch, L. E. (2004). Beyond the reading wars: Exploring the effect of child-instruction Interactions on growth in early reading. Scientific Studies of Reading, 8, 305-336. http://dx.doi.org/10.1207/s1532799xssr0804_1

Connor, C. M., Morrison, F. J., \& Slominski, L. (2006). Preschool instruction and children's literacy skill growth. Journal of Educational Psychology, 98, 665-689. http://dx.doi.org/10.1037/0022-0663.98.4.665

Connor, C. M., Morrison, F. J., \& Underwood, P. (2007). A second chance in second grade? The independent and cumulative impact of first and second grade reading instruction and students' letter-word reading skill growth. Scientific Studies of Reading, 11, 199-233. http://dx.doi.org/10.1080/10888430701344314

Connor, C. M., Son, S., Hindman, A., \& Morrison, F. J. (2005). Teacher qualifications, classroom practices, family characteristics and preschool experience: Complex effects on first graders' vocabulary and early reading outcomes. Journal of School Psychology, 43, 343-375.

Darling-Hammond, L. (1999). Reshaping teaching policy, preparation, and practice. Influences of the National Board for Professional Teaching Standards. Washington D.C.: American Association of Colleges for Teacher Education (AACTE) Publications.

Darling-Hammond, L. (2000). Teacher quality and student achievement. Education Policy Analysis Archives, 8(1), 1-44. [Online] Available: http://epaa.asu.edu/ojs/article/view/392

Denton, C., Foorman, B., \& Mathes, P. (2003). Schools that 'beat the odds': Implications for reading instruction. Remedial and Special Education. 24, 258-261. http://dx.doi.org/10.1177/07419325030240050101

Dewitz, P., Leahy, S. B., Jones, J., \& Sullivan, P. M. (2010). The essential guide to selecting and using core reading programs. Newark, DE: International Reading Association.

Education Market Research (2007). The complete K-12 newsletter: The convergence of traditional and electronic media in the school market. [Online] Available: http://www.ed-market.com/index.htm (January 20, 2007)

Education Market Research. (2002, December). The elementary reading market-2002-03 school year data. Rockaway Park, NY: Author. [Online] Available: http://www.ed-market.com/r_c_archives/display_article.php?article_id $=48$ (January 20, 2007)

Education Market Research. (2005, January). The elementary reading market. Rockaway Park, NY: Author. [Online] Available: http://www.ed-market.com/r_c_archives/display_article.php?article_id=75 (January 20, 
2007)

Farstrup, A. (December 2007). RTI: A vital concern for reading professionals. Reading Today, 25(3), 17.

Foorman, B. R. (2007). Primary prevention in classroom reading instruction. Teaching Exceptional Children, 39(5), 24-30.

Foorman, B. R., \& Moats, L. C. (2004). Conditions for sustaining research-based practices in early reading instruction. Remedial and Special Education, 25(1), 51-60. http://dx.doi.org/10.1177/07419325040250010601

Foorman, B. R., \& Torgesen, J. (2001). Critical elements of classroom and small-group instruction promote reading success in all children. Learning Disabilities Research \& Practice, 16, 203-212. http://dx.doi.org/10.1111/0938-8982.00020

Foorman, B. R., Francis, D. J., Davidson. K. C., Harm, M., \& Griffin. J. (2004). Variability in text features in six grade 1 basal reading programs. Scientific Studies of Reading, 82, 167-197. http://dx.doi.org/10.1207/s1532799xssr0802_4

Foorman, B. R., Francis, D. J., Fletcher, J. M., Schatschneider, C., \& Mehta, P. (1998). The role of instruction in learning to read: Preventing reading failure in at-risk children. Journal of Educational Psychology, 90, 37-55. http://dx.doi.org/10.1037//0022-0663.90.1.37

Foorman, B. R., Schatschneider, C., Eakin, M. N., Fletcher, J. M., Moats, L. C., \& Francis, D. J. (2006). The impact of instructional practices in grades 1 and 2 on reading and spelling achievement in high poverty schools. Contemporary Educational Psychology, 31, 1-29. http://dx.doi.org/10.1016/j.cedpsych.2004.11.003

Fuchs, D., \& Deshler, D. D. (2007). What we need to know about responsiveness to intervention (and shouldn't be afraid to ask). Learning Disabilities Research and Practice, 22, 129-136. http://dx.doi.org/10.1111/j.1540-5826.2007.00237.x

Fuchs, D., \& Fuchs, L. S. (2006). Introduction to Response to Intervention: What, why, and how valid is it? Reading Research Quarterly, 41, 93-99. http://dx.doi.org/10.1598/RRQ.41.1.4

Fuchs, D., Fuchs, L. S., \& Compton, D. L. (2004). Identifying reading disability by responsiveness-to-instruction: Specifying measures and criteria. Learning Disability Quarterly, 27, 216-227. http://dx.doi.org/10.2307/1593674

Fuchs, D., Mock, D., Morgan, P. L., \& Young, C. L. (2003). Responsiveness-to-intervention: Definitions, evidence, and implications for the learning disabilities construct. Learning Disabilities Research \& Practice, 18 , 157-171. http://dx.doi.org/10.1111/1540-5826.00072

Fuchs, L. S., \& Fuchs, D. (1998). Treatment validity: A unifying concept for reconceptualizing the identification of learning disabilities. Learning Disabilities Research \& Practice, 13, 204-219.

Fuchs, L. S., Fuchs, D., \& Speece, D. L. (2002). Treatment validity as a unifying construct for identifying learning disabilities. Learning Disability Quarterly, 25, 33-46. http://dx.doi.org/10.2307/1511189

Gersten, R., Compton, D., Connor, C. M., Dimino, J., Santoro, L., Linan-Thompson, S., \& Tilly, W D. (2008). Assisting students struggling with reading: Resonse to intervention and multi-tier intervention in the primary grades (NCEE Publication No. 2009-4045).

Gersten, R., \& Dimino, J. A. (2006). RTI (Response to Intervention): Rethinking special education for students with reading difficulties (yet again). Reading Research Quarterly, 41, 99-108. http://dx.doi.org/10.1598/RRQ.41.1.5

Gresham, F. M. (2002). Responsiveness to intervention: An alternative approach to the identification of learning disabilities. In R. Bradley, L. Danielson, \& D. P. Hallahan (Eds.), Identification of learning disabilities: Research to practice (pp. 467-519). Mahwah, NJ: Erlbaum.

Gresham, F. M., MacMillan, D. L., Beebe-Frankenberger, M. E., \& Bocian, K. M. (2000). Treatment integrity in learning disabilities intervention research: Do we really know how treatments are implemented? Learning Disabilities Research \& Practice, 15, 198-205. http://dx.doi.org/10.1207/SLDRP1504_4

International Reading Association. (2007). Request for Proposal-Description of Reading Instruction in the United States. Newark, DE: Author.

Johnson, E., Mellard, D. F., Fuchs, D., \& McKnight, M. A. (2006). Responsiveness to intervention (RTI): How to do it. Lawrence, KS: National Research Center on Learning Disabilities.

Juel, C., \& Minden-Cupp, C. (2000). Learning to read words: Linguistic units and instructional strategies. Reading Research Quarterly, 35, 458-492. http://dx.doi.org/10.1598/RRQ.35.4.2 
Kozol, J. (1991). Savage inequalities: Children in America's schools. New York: Crown Publishers, Inc.

Learning Disabilities Roundtable. (2002, July). Specific learning disabilities: Finding common ground. Washington, DC: American Institutes for Research. [Online] Available: http://www.ncld.org/content/view/280 (February 14, 2008)

Learning Disabilities Roundtable. (2005, February). Comments and recommendations on regulatory issues under the Individuals with Disabilities Education Improvement Act of 2004, Public Law 108-446. [Online] Available: http://www.nasponline.org/advocacy/2004LDRoundtableRecsTransmittal.pdf (February 15, 2008)

Loveless, T. (Ed.). (2001). The great curriculum debate: How should we teach reading and math. Washington, DC: Brookings Institutional Press.

Martin, D., Martin, M., \& Carvalho, K. (2008). Reading and learning-disabled children: Understanding the problem. The Clearing House, 81, 113-117. http://dx.doi.org/10.3200/TCHS.81.3.113-118

McGraw-Hill Education. (no date). Results with Open Court. New York, NY: Author. [Online] Available: https://www.sraonline.com/download/OCR/Research/SRA_OCR-Results.pdf (February 15, 2008)

McCutchen, D., Harry, D., Cunningham, A. E., Cox, S., Sidman, S., \& Covill, A. E. (2002). Reading teachers' knowledge of childrens' literature and English phonology. Annals of Dyslexia, 52, 207-228. http://dx.doi.org/10.1007/s11881-002-0013-x

Mellard, D. (2004). Understanding Responsiveness to Intervention in Learning Disabilities Determination. Lawrence, KS: National Research Center on Learning Disabilities.

Mraz, M., Algozzine, B., \& Kissel, B. (2009). The literacy coach's companion, PreK-3. Thousand Oaks, CA: Corwin Press.

Mraz, M., Algozzine, B., \& Watson, P. (2008). Perceptions and expectations of roles and responsibilities of literacy coaching. Literacy Research and Instruction, 47, 141-157. http://dx.doi.org/10.1080/19388070802059076

Mraz, M., Kissel, B., Algozzine, B., Babb, J., \& Foxworth, K. (2011). A collaborative professional development initiative supporting early literacy coaches. NHSA Dialog: A Research-to-Practice Journal for the Early Childhood Field, 14(3), 174-184.

National Research Council. (2002). Executive summary: Disproportionate representation of minority students in special education. Washington, DC: Author.

NJCLD [National Joint Committee on Learning Disabilities]. (2005). Responsiveness to intervention and learning disabilities. Washington, DC: Author. [Online] Available: http://www.ldonline.org/about/partners/njcld\#reports

No Child Left Behind Act of 2001. (2002). Pub.L. 107-110, 115 Stat. 1425, enacted January 8, 2002.

President's Commission on Excellence in Special Education. (2002). A new era: Revitalizing special education for children and their families. Washington, DC: Author.

Pressley, M., Wharton-Mc Donald, R., Allington, R., Block, C. C., Morrow, L., Tracey, D., ... Woo, D. (2001). A study of effective first-grade instruction. Scientific Study of Reading, 5, 35-58. http://dx.doi.org/10.1207/S1532799XSSR0501_2

Ravitch. D. (2001). It is time to stop the war. In T. Loveless (Ed.), The great curriculum debate: How should we teach reading and math (pp. 210-228). Washington, DC: Brookings Institutional Press.

Roit, M. (2000). Open Court: Administrator's Guide. Columbus, OH: SRA/McGraw-Hill.

Shannon, G. S., \& Bylsma, P. (2007). The nine characteristics of high-performing schools: A research-based resource for schools and districts to assist with improving student learning (2nd Ed.). Olympia, WA: Office of the Superintendent of Public Instruction.

Simmons, D. C., Kame'enui, E. J., Harn, B., Coyne, M. D., Stoolmiller, M., Santoro, L. E., Smith, S. B., Beck, C. T., \& Kaufman, N. K. (2007). Attributes of effective and efficient kindergarten reading intervention: An examination of instructional time and design specificity. Journal of Learning Disabilities, 40, 331-347. http://dx.doi.org/10.1177/00222194070400040401

Snow, C. E., Burns, M. S., \& Griffin, P. (Eds.). (1998). Preventing reading difficulties in young children. 
Washington, DC: National Academy Press.

SRA/McGraw Hill. (2000). Open Court Reading (C2000. DeSoto, TX: Author. [Online] Available: http://www.sraonline.com

Taylor, B. M., Pearson, P. D., Clark. K., \& Walpole, S. (2000). Effective schools and accomplished teachers: Lessons about primary-grade reading instruction in low income schools. Elementary School Journal, 101, 121-165. http://dx.doi.org/10.1086/499662

U. S. Department of Education. (2002, November 26). The No Child Left Behind Act, Title I: Improving the Academic Achievement of the Disadvantaged Summary of Final Regulations [Press Release]. [Online] Available: http://www.ed.gov/PressReleases/11-2002/regs_sum.html

Vaughn, S., \& Fuchs, L. S. (2003). Redefining learning disabilities as inadequate response to instruction: The promise and potential problems. Learning Disabilities Research \& Practice, 18, 137-146. http://dx.doi.org/10.1111/1540-5826.00070

Vaughn, S., Linan-Thompson, S., \& Hickman, P. (2003). Response to instruction as a means of identifying students with reading/learning disabilities. Exceptional Children, 69, 391-409.

Wallace, F., Blase, K., Fixsen, D., \& Naoom, S. (2008). Implementing the findings of research: Bridging the gap between knowledge and practice. Alexandria, VA: Educational Reseach Service.

Wharton-McDonald, R,. Pressley, M,. \& Hampston, J. M. (1998). Literacy instruction in nine first-grade classrooms: Teacher characteristics and student achievement. The Elementary School Journal. 99, 101-128. http://dx.doi.org/10.1086/461918

What's hot focus topics. (February 2008). Reading Today, 25(4), 12, 13.

Ysseldyke, J. E., \& Algozzine, B. (1982). Critical issues in special and remedial education. Boston, MA: Houghton Mifflin.

Ysseldyke, J. E., \& Algozzine, B. (1984). Introduction to special education. Boston, MA: Houghton Mifflin.

Ysseldyke, J. E., Algozzine, B., \& Thurlow, M. L. (2000). Critical issues in special and remedial education $\left(3^{\text {rd }}\right.$ ed.). Boston, MA: Houghton Mifflin.

Table 1. Kindergarten reading instruction for open court 2000

\begin{tabular}{|c|c|c|c|}
\hline Instructional Component & \multicolumn{3}{|c|}{ Classroom Variation } \\
\hline \multirow[t]{7}{*}{ Sounds, Letters, and Language } & \multicolumn{3}{|c|}{ Recommended Time: $10-15$ minutes } \\
\hline & \multicolumn{3}{|c|}{ Observed Time: } \\
\hline & \multicolumn{3}{|c|}{$M=11.29$ minutes, $S D=2.98$} \\
\hline & \multicolumn{3}{|c|}{ Minimum $=7$, Maximum $=15$} \\
\hline & \multicolumn{3}{|c|}{$n=7(64 \%)$} \\
\hline & \multicolumn{3}{|c|}{ Rating } \\
\hline & Not Available & Satisfactory & Well Done \\
\hline Children are engaged in the activity. $(n=7)$ & $0.0 \%$ & $57.1 \%$ & $42.9 \%$ \\
\hline Children are discussing print concepts. $(n=6)$ & $16.7 \%$ & $33.3 \%$ & $50.0 \%$ \\
\hline Children are manipulating words/pictures. $(n=4)$ & $50.0 \%$ & $25.0 \%$ & $25.0 \%$ \\
\hline
\end{tabular}




\begin{tabular}{|c|c|c|c|}
\hline Instructional Component & \multicolumn{3}{|c|}{ Classroom Variation } \\
\hline \multirow[t]{6}{*}{ Phonemic Awareness } & \multicolumn{3}{|c|}{ Recommended Time: $10-15$ minutes } \\
\hline & \multicolumn{3}{|c|}{ Observed Time: } \\
\hline & \multicolumn{3}{|c|}{$M=12.20$ minutes, $S D=8.47$} \\
\hline & \multicolumn{3}{|c|}{ Minimum=2, Maximum=29 } \\
\hline & \multicolumn{3}{|c|}{$n=10(91 \%)$} \\
\hline & \multicolumn{3}{|c|}{ Rating } \\
\hline Area & Not Available & Satisfactory & Well Done \\
\hline Focus of lesson is manipulating sounds. $(n=9)$ & $11.1 \%$ & $33.3 \%$ & $55.6 \%$ \\
\hline Activities focus on sounds not letters. $(n=9)$ & $0.0 \%$ & $44.4 \%$ & $55.6 \%$ \\
\hline Children are engaged in word play. $(n=8)$ & $0.0 \%$ & $75.0 \%$ & $25.0 \%$ \\
\hline Identify or listen for sounds of words. $(n=9)$ & $0.0 \%$ & $55.6 \%$ & $44.4 \%$ \\
\hline Children blend parts of words to make sounds. $(n=8)$ & $0.0 \%$ & $75.0 \%$ & $25.0 \%$ \\
\hline \multirow[t]{6}{*}{ Letter Recognition } & \multicolumn{3}{|c|}{ Recommended Time: $10-15$ minutes } \\
\hline & \multicolumn{3}{|c|}{ Observed Time: } \\
\hline & \multicolumn{3}{|c|}{$M=17.00, S D=9.58$} \\
\hline & \multicolumn{3}{|c|}{ Minimum $=5$, Maximum $=35$} \\
\hline & \multicolumn{3}{|c|}{$n=9(82 \%)$} \\
\hline & \multicolumn{3}{|c|}{ Rating } \\
\hline Area & Not Available & Satisfactory & Well Done \\
\hline Activities focus on letter names and formation. $(n=8)$ & $0.0 \%$ & $62.5 \%$ & $37.5 \%$ \\
\hline Teacher models letter formation. $(n=8)$ & $37.5 \%$ & $25.0 \%$ & $37.5 \%$ \\
\hline Reading/writing workbook pages are guided. $(n=9)$ & $44.4 \%$ & $55.6 \%$ & $0.0 \%$ \\
\hline \multirow[t]{7}{*}{ Reading and Responding } & \multicolumn{3}{|c|}{ Recommended Time: 20 minutes } \\
\hline & \multicolumn{3}{|c|}{ Observed Time: } \\
\hline & \multicolumn{3}{|c|}{$M=20.25$ minutes, $S D=12.10$} \\
\hline & \multicolumn{3}{|c|}{ Minimum $=5$, Maximum $=45$} \\
\hline & \multicolumn{3}{|c|}{$n=8(73 \%)$} \\
\hline & \multicolumn{3}{|c|}{ Rating } \\
\hline & Not Available & Satisfactory & Well Done \\
\hline Teacher reads aloud from the Big Books or others. $(n=8)$ & $0.0 \%$ & $62.5 \%$ & $37.5 \%$ \\
\hline Children browse Big Books. $(n=6)$ & $66.7 \%$ & $16.7 \%$ & $16.7 \%$ \\
\hline Teacher makes connections to unit theme. $(n=8)$ & $62.5 \%$ & $25.0 \%$ & $12.5 \%$ \\
\hline Teacher reviews selection vocabulary. $(n=8)$ & $0.0 \%$ & $75.0 \%$ & $25.0 \%$ \\
\hline Comprehension strategies are modeled. $(n=7)$ & $42.9 \%$ & $42.9 \%$ & $14.3 \%$ \\
\hline Children are encouraged to ask questions. $(n=8)$ & $37.5 \%$ & $37.5 \%$ & $25.0 \%$ \\
\hline Children are encouraged to make connections. $(n=8)$ & $12.5 \%$ & $37.5 \%$ & $50.0 \%$ \\
\hline Comprehension skills are directly taught. $(n=8)$ & $75.0 \%$ & $12.5 \%$ & $12.5 \%$ \\
\hline Concept/Question Board is up and being used. $(n=8)$ & $25.0 \%$ & $37.5 \%$ & $37.5 \%$ \\
\hline Children are working on unit projects. $(n=6)$ & $33.3 \%$ & $33.3 \%$ & $33.3 \%$ \\
\hline
\end{tabular}




\begin{tabular}{|c|c|c|c|}
\hline Instructional Component & \multicolumn{3}{|c|}{ Classroom Variation } \\
\hline \multirow[t]{6}{*}{ Independent Work Time } & \multicolumn{3}{|c|}{ Recommended Time: $15-30$ minutes } \\
\hline & \multicolumn{3}{|c|}{ Observed Time: } \\
\hline & \multicolumn{3}{|c|}{$M=37.11$ minutes, $S D=9.97$} \\
\hline & \multicolumn{3}{|c|}{ Minimum $=23$, Maximum $=50$} \\
\hline & \multicolumn{3}{|c|}{$n=9(82 \%)$} \\
\hline & \multicolumn{3}{|c|}{ Rating } \\
\hline Area & Not Available & Satisfactory & Well Done \\
\hline Independent Work Time (IWT) is scheduled. $(n=9)$ & $0.0 \%$ & $77.8 \%$ & $22.2 \%$ \\
\hline IWT rules are posted. $(n=8)$ & $37.5 \%$ & $62.5 \%$ & $0.0 \%$ \\
\hline IWT areas are clearly established and labeled. $(n=9)$ & $11.1 \%$ & $55.6 \%$ & $33.3 \%$ \\
\hline Teacher introduces activities prior to use. $(n=6)$ & $16.7 \%$ & $16.7 \%$ & $66.7 \%$ \\
\hline Reading materials are available to support unit. $(n=8)$ & $75.0 \%$ & $12.5 \%$ & $12.5 \%$ \\
\hline Materials are available for building fluency. $(n=9)$ & $22.2 \%$ & $33.3 \%$ & $44.4 \%$ \\
\hline Assistant is providing support. $(n=8)$ & $12.5 \%$ & $50.0 \%$ & $37.5 \%$ \\
\hline Teacher provides direct instruction. $(n=9)$ & $33.3 \%$ & $44.4 \%$ & $22.2 \%$ \\
\hline \multirow[t]{6}{*}{ Independent, Collaborative, and Whole Group Writing } & \multicolumn{3}{|c|}{ Recommended Time: $15-20$ minutes } \\
\hline & \multicolumn{3}{|c|}{ Observed Time: } \\
\hline & \multicolumn{3}{|c|}{$M=27.29$ minutes, $S D=9.39$} \\
\hline & \multicolumn{3}{|c|}{ Minimum $=10$, Maximum $=38$} \\
\hline & \multicolumn{3}{|c|}{$n=7(64 \%)$} \\
\hline & \multicolumn{3}{|c|}{ Rating } \\
\hline Area & Not Available & Satisfactory & Well Done \\
\hline Teacher provides direct writing process instruction. $(n=6)$ & $66.7 \%$ & $33.3 \%$ & $0.0 \%$ \\
\hline Children are involved in independent writing. $(n=6)$ & $0.0 \%$ & $83.3 \%$ & $16.7 \%$ \\
\hline Writing seminar is being held. $(n=6)$ & $33.3 \%$ & $50.0 \%$ & $16.7 \%$ \\
\hline Literacy skills are directly taught. $(n=8)$ & $25.0 \%$ & $62.5 \%$ & $12.5 \%$ \\
\hline Teacher follows with cross curriculum activities. $(n=5)$ & $40.0 \%$ & $40.0 \%$ & $20.0 \%$ \\
\hline
\end{tabular}


Table 2 Kindergarten classroom organization for open court 2000 reading program

\begin{tabular}{|l|ccc|}
\hline \multirow{2}{*}{ Program Elements } & \multicolumn{3}{c|}{ Observation } \\
\cline { 2 - 4 } Alphabet Sound Cards & Not Available & Satisfactory & Well Done \\
Word Wall & $0.0 \%$ & $9.1 \%$ & $90.0 \%$ \\
Reading Area & $9.1 \%$ & $27.3 \%$ & $63.6 \%$ \\
Listening Area & $27.3 \%$ & $54.5 \%$ & $18.2 \%$ \\
Writing Area & $45.5 \%$ & $18.2 \%$ & $36.4 \%$ \\
Concept/Question Board & $36.4 \%$ & $63.6 \%$ & $0.0 \%$ \\
Inquiry Area & $9.1 \%$ & $45.5 \%$ & $45.5 \%$ \\
Pocket Chart/Cards & $90.9 \%$ & $9.1 \%$ & $0.0 \%$ \\
Board Area & $9.1 \%$ & $45.5 \%$ & $45.5 \%$ \\
Floor Area & $27.3 \%$ & $36.4 \%$ & $36.4 \%$ \\
Table Area & $0.0 \%$ & $18.2 \%$ & $81.8 \%$ \\
Program Resources & $27.3 \%$ & $45.5 \%$ & $27.3 \%$ \\
Big Books & & & $36.4 \%$ \\
Decodables & $18.2 \%$ & $45.5 \%$ & $36.4 \%$ \\
Workbooks/Reproducibles & $0.0 \%$ & $63.6 \%$ & $36.4 \%$ \\
Manipulative Kit & $0.0 \%$ & $63.6 \%$ & $18.2 \%$ \\
\hline
\end{tabular}

